\title{
Manajemen Nutrisi dan Terapi Diet pada Pasien Hipertensi
}

\author{
Yusrah Taqiyah ${ }^{1}$, Rahmawati Ramli ${ }^{2}$, Najihah ${ }^{3 *}$ \\ 1,2Program Studi Ilmu Keperawatan, Universitas Muslim Indonesia, Makassar \\ ${ }^{3}$ Jurusan Keperawatan, Universitas Borneo Tarakan
}

\author{
*Najihah \\ Email:714.najihah@gmail.com \\ Alamat: Jl. Amal Lama No. 01, \\ Tarakan
}

\section{History Artikel}

Received : 15-07-2021

Accepted: $30-08-2021$

Published: $31-08-2021$

\begin{abstract}
Abstrak.
Prevalensi kejadian hipertensi di Indonesia cukup tinggi dampak dari kejadian hipertensi memerlukan perhatian dan penanganan khusus. Untuk mencegah hipertensi dan mengendalikan hipertensi beberapa hal dapat dikontrol diantaranya berat badan berlebih, aktifitas fisik, merokok, serta asupan nutrisi. Tujuan pengabdian ini yaitu mensosialisasikan Manajemen Nutrisi dan Terapi Diet pada Pasien Hipertensi, Kegiatan ini dilakukan dengan metode ceramah, diskusi dan demonstrasi. Hasil kegiatan ini menunjukkan peningkatan pengetahuan dimana hasil dari pretest yang dilakukan pada 24 pasien yang diberikan kuesioner dengan 10 pertayaan dengan hasil pretest yaitu $17 \%$ memiliki pengetahuan baik, $25 \%$ pengetahuan cukup, $58 \%$ yang memiliki pengetahuan kurang. Setelah diberikan edukasi dan demonstrasi tingkat pengetahuan pasien yaitu, $83 \%$ memiliki pengetahuan baik dan $16 \%$ memiliki pengetahuan cukup. Kesimpulan dengan adanya kegiatan ini pasien hipertensi yang di rawat di RSU Ibnu Sina memiliki pengetahuan yang cukup dalam manajemen nutrisi dan terapi diet untuk mengurangi terjadinya serangan penyakit yang dialami.
\end{abstract}

Kata Kunci : Manajemen Nutrisi; Diet; Hipertensi

\begin{abstract}
The prevalence of hypertension in Indonesia is quite high, the impact of the incidence of hypertension requires special attention and treatment. To prevent hypertension and control hypertension, several things can be controlled including excess body weight, physical activity, smoking, and nutritional intake. The purpose of this service is to socialize Nutrition Management and Diet Therapy for Hypertensive Patients. This activity is carried out using lecture, discussion and demonstration methods. The results of this activity are showing an increase in knowledge where the results of the pretest conducted on 24 patients who were given a questionnaire with 10 questions with the pretest results, namely, 17\% had good knowledge, 25\% had sufficient knowledge, $58 \%$ had poor knowledge. After being given education and demonstration of the patient's level of knowledge, $83 \%$ had good knowledge and $16 \%$ had sufficient knowledge. The conclusion with this activity is that hypertensive patients treated at Ibnu Sina General Hospital have sufficient knowledge in nutritional management and diet therapy to reduce the occurrence of disease attacks they experience
\end{abstract}

Keyword: Nutrition Management; Diet; Hypertension 
Kesehatan, 2018). Di jombang sendiri kasus hipertensi juga meningkat

\section{Pendahuluan}

Asupan makanan yang mengandung tinggi natrium menjadi salah satu faktor resiko utama penyebab terjadinya penyakit hipertensi (Prynn et al., 2018). Nutrisi yang rendah seperti asupan rendah lemak, protein, karbohidrat, dapat menyebabkan penurunan massa tubuh dan gangguan pada penyerapan lemak (Sujati, Tanto Hariyanto, 2016). Frekuensi makan, jenis makanan yang dikonsumsi, makanan siap saji, dan makanan berkadar garam tinggi serta mengandung rendah serat akan memicu terjadinya penyakit vaskuler dan hipertensi. Hipertensi atau tekanan darah tinggi masih dianggap sebagai masalah kesehatan yang serius bahkan menjadi awal dari berbagai macam masalah kardiovaskuler lainnya dan dapat menimbulkan kematian (Purnamasari, 2017). Kurangnya pengetahuan dari dampak dan pencegahan yang harus dilakukan oleh penderita hipertensi mengakibatkan semakin penderita hipertensi disetiap tahun. Sebagian besar penderita hipertensi cenderung mengesampingkan naik atau turunnya tekanan darah tanpa dikontrol dan tidak segera diatasi dengan cepat, sehingga dapat menimbulkan komplikasi yang serius (Abdul, 2018).

Estimasi jumlah kasus hipertensi tidak hanya terjadi di negara maju tetapi juga di negara berkembang seperti di Indonesia sebesar 63.309.620 jiwa. Penyakit hipertensi diperkirakan telah menyebabkan peningkatan angka morbiditas secara global sebesar $4,5 \%$. Jumlah tersebut diperkirakan akan mengalami peningkatan $15-20 \%$ pada tahun 2025 (Dinkes, 2018). Berdasarkan hasil Riset Kesehatan Dasar (RISKESDAS) Jawa Timur pada tahun 2018 jumlah penduduk yang berusia $>18$ tahun yang telah didiagnosa terkena penyakit hipertensi sebesar $36,3 \%$ (Dinkes, 2018). Jumlah ksus hipertensi pada tahun 2018 meningkat daripada tahun sebelumnya, yaitu sekitar $20,43 \%$ atau sebanyak 1.828.699 penduduk, dengan proporsi lakilaki sebesar $20,83 \% \quad(825,412$ penduduk $)$ dan perempuan sebesar $20,11 \%$ atau sebanyak 1.003.257 penduduk (Kementrian dibandingkan dengan tahun sebelumnya, yaitu sebesar 20,59\% atau sebanyak 60.607 penduduk (Dinkes jombang, 2017).Faktor risiko hipetensi diantaranya umur, riwayat keluarga, berat badan berlebih, kurang aktifitas fisik, merokok, asupan natrium berlebih, asupan kalium, kalsium, magnesium kurang, konsumsi alkohol serta stress. Pada masa lalu manajemen hipertensi diutamakan dengan menggunakan obat anti-hipertensi disertai diet rendah garam. Seiring dengan perkembangan ilmu pengetahuan dan teknologi, dengan berdasarkan bukti dari berbagai hasil penelitian (evidence based), telah disusun suatu pedoman yang menggambarkan peran gizi yang sangat penting dalam manajemen hipertensi.

Manajemen untuk pasien pre hipertensi dimulai dengan terapi non-farmakologik yaitu modifikasi gaya hidup (lifestyle) yang sangat erat kaitannya dengan gizi. Apabila target tekanan darah tidak tercapai akan diterapkan terapi farmakologik. Dengan demikian setiap ahli gizi/dietisien yang akan memberikan edukasi dan konseling kepada pasien pre hipertensi maupun hipertensi perlu memahami rekomendasi baru mengenai manajemen hipertensi yang komprehensif sehingga tujuan terapi diet dapat tercapai.

Tujuan dari penatalaksanaan diet adalah untuk membantu menurunkan tekanan darah dan mempertahankan tekanan darah menuju normal. Disamping itu, diet juga ditujukan untuk menurunkan faktor risiko lain seperti berat badan yang berlebih, tingginya kadar lemak kolesterol dan asam urat dalam darah. Harus diperhatikan pula penyakit degeneratif lain yang menyertai darah tinggi seperti jantung, ginjal dan diabetes mellitus. Prinsip diet pada penderita hipertensi adalah sebagai berikut : · Makanan beraneka ragam dan gizi seimbang., Jenis dan komposisi makanan disesuaikan dengan kondisi penderita, Jumlah garam dibatasi sesuai dengan kesehatan penderita dan jenis makanan dalam daftar diet

Berdasarkan uraian di atas, maka kami tertarik untuk melakukan Penerapan Diet dan Terapi Gizi sebagai terapi 
nonfarmakologi pada pasien Hipertensi di RSU Ibnu Sina Makassar. Dari analisis situasi mitra tersebut di atas maka dirumuskan permasalahan sebagai berikut: Kurangnya pengetahuan pasien tentang Gizi dan Terapi Diet untuk mengatasi Hipertensi.

\section{Metode}

Metode Pelaksanaan pengabdian ini meliputi: Ceramah, Tanya Jawab, Diskusi dan Demonstrasi. Tahap ini dimulai dari Tahap I persiapan yaitu membuat surat tugas dari instusi untuk kegiatan pelaksanaan pengabdian di RS Ibnu Sina, dilanjutkan dengan persiapan alat dan instrument, kontrak awal dengan pasien, membagikan kuesioner pretest kepada pasien. Pada pelaksanaan diawali dengan persentasi materi tentang penyakit hipertensi, penyebab, tanda gejala, pengobatan, serta gizi dan terapi diet pada pasien hipertensi, kegiatan penyuluhan dilakukan selama 45 menit dilanjutkan dengan demonstrasi pembuatan jadwal (ADL) pola nutrisi dan terapi diet. Tahap akhir posttest pembagian kuesioner menilai evaluasi tingkat pengetahuan pasien.

Bentuk partipisi mitra berkoordinasi dengan pasien dalam memfasilitasi pelaksanaan kegiatan yang akan dilakukan termasuk mengkoordinasi pasien, serta menyiapkan tempat untuk pelaksanaan kegiatan

Setelah program ini selesai, pasien dapat melakukan deteksi dini ketika serangan hipertensi terjadi dengan adanya peningkatan pengetahuan dan mengurangi beratnya gejala dengan cara mengontrol pola makan dan penerapan terapi diet yang dapat mengurangi beratnya gejala hipertensi yang dialami

\section{Hasil dan Pembahasan}

Kepala Ruangan Assalam RSU Ibnu

Sina membantu untuk memfasilitasi dalam melakukan pemberian edukasi manajemen nutrisi pada pasien Hipertensi yaitu, mengarahkan pasien untuk mengikuti kegiatan pengabdian. Pasien yang menjadi peserta kegiatan berjumlah sebanyak 24 orang yang memiliki latar belakang pendidikan berbeda-beda. Pelaksanaan kegiatan pemberian edukasi dan demonstrasi Manajemen nutrisi dan terapi diet dilakukan di ruang perawatan Assalama Kamar 2 dan 3 kelas 2 yang diawali dengan pretest untuk mengetahui pengetahuan serta pemahaman pasien tentang penyakit hipertensi serta manajemen nutrisi dan terapi diet oleh tim pengabdi/pemateri dilakukan dengan bantuan Media edukasi dan Alat edukasi berupa leafleat dan spanduk yang disampaiakan dengan metode ceramah. Materi ini berisi tentang definisi hipertensi, etiologi, manifestasi klinis, pengobatan, pemeriksaan penunjang, komplikasi, manajemen nutrisi serta terapi diet pasien hipertensi. Pada akhir pemberian materi dibuka sesi Tanya jawab dan ada beberapa pasien yang bertanya berkaitan dengan materi yang disampaikan.

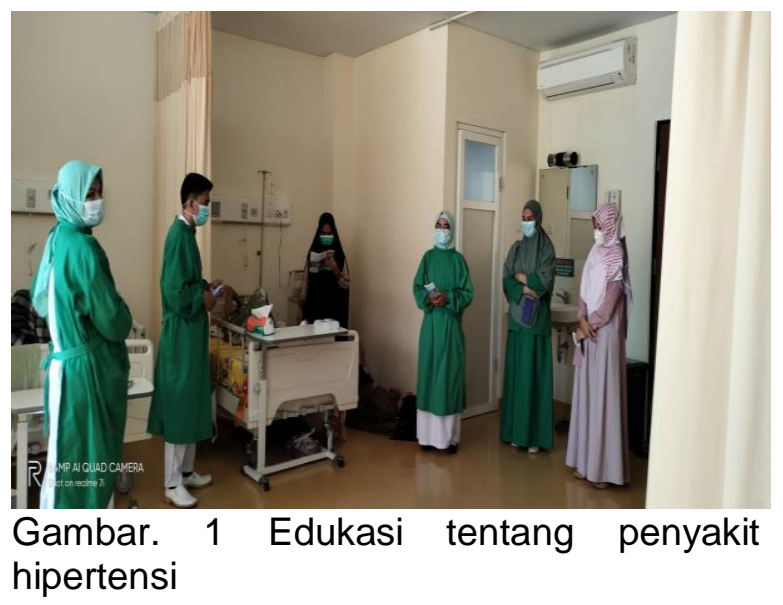

Setelah dilakukan edukasi tim pengabdi melanjutkan dengan kegiatan demonstrasi manajemen nutrisi dan terapi diet keesokan harinya dengan kolaborasi dengan tim analis gizi dalam membuat dan mengatur menu daftar harian pada pasien hipertensi, yang terdiri dari menu makan pagi dan selingan yang terdiri dari ubi jalar rebus,telur mata sapi selingan buah papaya, makan siang nasi putih, sayur asem tanpa garam ikan bakar, tahu rebus dan selingan buah semangka, serta makan malam nasi putih, ayam panggang, sayur sup tanpa garam hidangan penutup dengan segelas susu tinggi kalsium. Menu yang dibuat melalui beberapa tes diantara tes rasa, tes komposisi, dan terakhir penilaian sajian dalam pengolahan makanan tim 
menggunakan bahan dasar yang aman untuk pasien hipertensi diantara nya minyak goring yang digunakan adalah minyak olive oil, takaran untuk menu sajian disesuaikan dengan derajat hipertensi serta umur dan berat badan pasien.

Pengukuran terhadap kegiatan edukasi dan demonstrasi dilakukan dengan menggunakan kuesioner pre dan post. Hasil dari pretest yang dilakukan pada 24 pasien yang diberikan kuesioner dengan 10 pertayaan dengan hasil pretest yaitu, 17\% memiliki pengetahuan baik, 25\% pengetahuan cukup, 58\% yang memiliki pengetahuan kurang. Setelah diberikan edukasi dan demonstrasi tingkat pengetahuan pasien yaitu, $83 \%$ memiliki pengetahuan baik, dan $16 \%$ pengetahuan cukup Hasil dari posttest sebanyak 20 orang kader (85\%) dari 24 peserta memiliki pengatahuan dalam kategori baik. Dapat disimpulkan terjadi peningkatan pengetahuan.

Dengan adanya pemberian edukasi dan demonstrasi ini diharapkan para pasien dapat mengetahui deteksi dini gejala serangan dari hipertensi serta mampu menerapkan manajemen nutrisi dan terapi diet untuk mengurangi dampak dari gejala hipertensi yang dialami. Sehinggah pasien dapat hidup lebih produktif dan terbebas dari penyakit.

Hasil pengabdian ini sejalan dengan teori yang mengatakan bahwa Pendekatan diet dalam memodifikasi tekanan darah merupakan strategi yang penting dalam menurunkan kejadian hipertensi. Beberapa penelitian yang menunjukkan bahwa asupan makanan yang dikonsumsi memengaruhi terhadap tekanan darah. Terapi non- farmakologis yang efektif dalam menurunkan tekanan darah yaitu dengan mengadopsi pola diet DASH, mengurnagi makanan lemak jenuh total, mengkonsumsi tinggi kalium, membatasi jumlah natrium dan membatasi konsumsi alcohol. Keberhasilan program manajemen diet akan jauh lebih baik, ketika keluarga ikut berpartisipasi (Nuraini, 2015). Ketika anggota keluarga ikut terlibat dalam intervensi manajemen diet, mereka akan memberikan dukungan pada pasien. Penelitian yang dilakukan oleh (Wahyuningsih, 2018) menemukan bahwa pasien yang mendapakan dukungan yang baik dari anggota keluarganya memiliki perilaku manajemen diet lebih baik.

Berdasarkan literatur review dari beberapa artikel jenis management nutrisi yang dilakukan menunjukkan bahwa dalam pemenuhan kebutuhan nutrisi pada penderita hipertensi yaitu sebagian besar menggunakan management nutrisi asupan protein, kalium, dan rendah natrium dengan presentase sebesar (55\%). Dan yang paling jarang diberikan yaitu sebagian kecil menggunakan management diet rendah garam dengan presentase (9\%). Maka sangat dianjurkan untuk diterapkan dalam kehidupan sehari-hari bagi penderita hipertensi untuk memenuhi nutrisi dan gizi yang seimbang dengan meningkatkan asupan protein, kalium, dan rendah natrium agar tekanan darah dapat terkontrol dengan baik dan dalam jangka waktu yang panjang dapat menurunkan tekanan darah.

\section{Kesimpulan}

Dengan edukasi yang baik dapat meningkatkan pengetahuan pasien tentang deteksi dini renjatan dari penyakit hipertensi dan melalui implementasi penerapan manajemen nutrisi dan terapi diet dapat menurunkan gejala dalam penyakit hipertensi.

\section{Daftar Pustaka}

Abdul, M. R. (2018) „Pengaruh Diit Rendah Garam Terhadap Tekanan Darah Pada Penderita Hipertensi Usia Lansia", Jurnal Insan Cendekia Medika, pp. 1-108.

Dinkes. (2018). Hasil Utama Riset Kesehatan Dasar Jawa Timur 2018", Jakarta: Badan Penelitian dan Pengembangan Kesehatan, Kementrian Kesehatan Republik Indonesia, pp. 1-82.

Dinkes jombang (2017) „Profil Kesehatan Kabupaten Jombang Tahun 2017", Dinas Kesehatan kabupaten Jombang, pp. 82-88.

Kemenkes (2018) „Pola makan Diabetes melitus", (2009), pp. 1-24. 
Purnamasari, P. D. (2017) „Hubungan

Program Pengelolaan Penyakit

Kronis (PROLANIS) Terhadap

Status Kesehatan Penderita

Hipertensi", pp. 1-136.

Prynn, J. E. et al. (2018) „Dietary sodium intake in urban and rural Malawi, and directions for future interventions", American Journal of Clinical Nutrition, 108(3), pp. 587593. doi: 10.1093/ajcn/nqy125.

Nuraini, B. (2015). Risk Factors of Hipertension. J Majority, Vol. 5

Wahyuningsih, R. (2018), Penatalaksanaan

Diet pada Pasien. Yogyakarta:

Graha IImu 